\title{
Innate Lymphocytes in Psoriasis
}

OPEN ACCESS

Edited by:

Arthur Mortha,

University of Toronto, Canada

Reviewed by:

Mélanie Bruchard,

INSERM U1231 Lipides, Nutrition,

Cancer (LNC), France

Stefania Madonna,

Institute of Dermatology Immaculate

(IRCCS), Italy

*Correspondence:

Irah L. King

irah.king@mcgill.ca

tPresent address:

Barbara Polese

University of Liège, GIGA Institute,

Liège, Belgium

Specialty section:

This article was submitted to NK and Innate Lymphoid Cell Biology,

a section of the journal

Frontiers in Immunology

Received: 30 October 2019

Accepted: 29 January 2020

Published: 21 February 2020

Citation:

Polese $B$, Zhang $H$, Thurairajah $B$ and King IL (2020) Innate Lymphocytes in

Psoriasis. Front. Immunol. 11:242.

doi: 10.3389/fimmu.2020.00242

\author{
Barbara Polese $^{1 \dagger}$, Hualin Zhang ${ }^{1}$, Bavanitha Thurairajah ${ }^{1}$ and Irah L. King ${ }^{1,2 *}$ \\ ${ }^{1}$ Meakins-Christie Laboratories, Department of Microbiology and Immunology, McGill University Health Centre Research \\ Institute, Montreal, QC, Canada, ${ }^{2}$ Meakins-Christie Laboratories, Department of Medicine, McGill University Health Centre \\ Research Institute, Montreal, QC, Canada
}

Skin is a fundamental component of our host defense system that provides a dynamic physical and chemical barrier against pathogen invasion and environmental insults. Cutaneous barrier function is mediated by complex interactions between structural cells such as keratinocytes and diverse lineages of immune cells. In contrast to the protective role of these intercellular interactions, uncontrolled immune activation can lead to keratinocyte dysfunction and psoriasis, a chronic inflammatory disease affecting $2 \%$ of the global population. Despite some differences between human and murine skin, animal models of psoriasiform inflammation have greatly informed clinical approaches to disease. These studies have helped to identify the interleukin (IL)-23-IL-17 axis as a central cytokine network that drives disease. In addition, they have led to the recent description of long-lived, skin-resident innate lymphocyte and lymphoid cells that accumulate in psoriatic lesions. Although not completely defined, these populations have both overlapping and unique functions compared to antigen-restricted $\alpha \beta$ T lymphocytes, the latter of which are well-known to contribute to disease pathogenesis. In this review, we describe the diversity of innate lymphocytes and lymphoid cells found in mammalian skin with a special focus on $\alpha \beta$ T cells, Natural Killer T cells and Innate Lymphoid cells. In addition, we discuss the effector functions of these unique leukocyte subsets and how each may contribute to different stages of psoriasis. A more complete understanding of these cell types that bridge the innate and adaptive immune system will hopefully lead to more targeted therapies that mitigate or prevent disease progression.

Keywords: innate, psoriasis, lymphocyte, skin, disease

\section{INTRODUCTION}

The skin is the largest barrier organ. The most superficial layer of mammalian skin consists of an avascular, stratified epithelial layer that provides a physical and chemical barrier to environmental insults, is responsible for hair formation and supports a diverse commensal microbial community that promotes colonization resistance to invasive pathogens. Underlying the epidermis is the dermis composed of a fibroblast network providing structure for a complex neurovascular system that regulates heat transfer, pain sensation, and host defense (1). The epidermis and dermis harbor unique leukocyte subsets that are not only central to cutaneous immunity, but also contribute to basic skin physiology including wound healing, hair follicle cycling, and lipid production by sebaceous glands. Given the intimate relationship between immune-structural cell interactions, it stands to reason that aberrant communication within this compartment can lead to altered host defense mechanisms and/or dysregulated skin inflammation and disease. One of the most common cutaneous inflammatory diseases is psoriasis. Affecting between 2 and $5 \%$ of the adult 


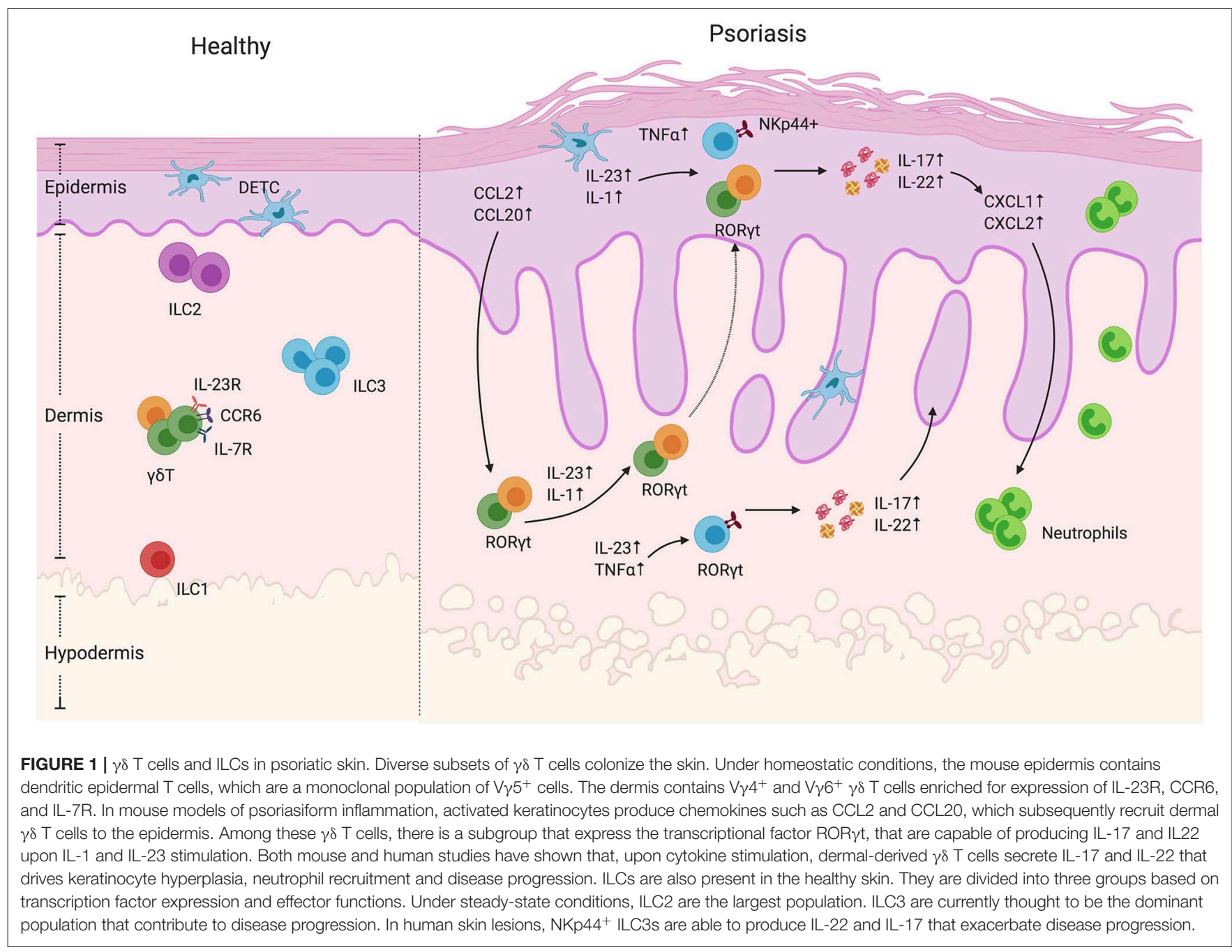

population in developed countries, psoriasiform inflammation varies in severity but is most commonly characterized by red, scaly plaques across the surface of the body in a form referred to as psoriasis vulgaris. Although the etiology of psoriasis has not been identified, both environmental and genetic factors have been shown to contribute to incidence and severity of disease (13). Importantly, psoriasis is associated with comorbidities such as atherosclerosis and metabolic syndrome suggesting systemic dysregulation of the immune response in these patients providing further motivation for understanding disease pathogenesis (1, 4). Despite some differences between human and rodent skin, animal models of "psoriasiform" inflammation have been instrumental in identifying the immunological mechanisms underlying psoriasis development. For example, the models described in more detail below have helped to determine the interleukin (IL)-23/IL-17 axis as central to disease progression $(1,5)$. The essential role of these cytokines has been validated by the clinical efficacy of humanized monoclonal antibodies targeting TNF $\alpha$, IL-23, IL-17A, and the IL-17 receptor $(6,7)$. However, these treatment approaches have limitations. First, they are not curative; symptoms reappear upon cessation of treatment. Thus, biologics must be given throughout the patient's lifetime. Second, the IL-23/IL-17 immune axis plays an important role in protection against cutaneous pathogens such as Candida and pathobiotic spp. of Staphylococcus areus $(8,9)$, thus raising questions about the long-term use of these treatments regarding susceptibility to infection. Furthermore, these biologics do not specifically target the skin and may compromise host defense at other barrier sites such as the intestine. Therefore, further investigation into the initiating factors that drive psoriatic disease will not only enrich our knowledge of skin biology in general, but lead to more targeted, tissue-specific treatments for this chronic inflammatory disease.

The recent discovery of immune cell subsets that are resident to the skin such as $\gamma \delta \mathrm{T}$ cells and innate lymphoid cells (ILCs) has prompted a growing interest in how these and other better known cell types that blur the separation between the innate and adaptive immune system such as Natural Killer (NK) cells and NKT cells contribute to psoriasiform inflammation. Indeed, these cells serve as acute sensors of infection and tissue 
injury without the need for specific recognition of antigen. While these properties have likely evolved to respond rapidly to tissue changes, their non-specific activation requirements leave them susceptible to hyperreactive responses against innocuous stimuli. In this review, we describe the diversity of innate lymphocyte lineages present in the skin and our current understanding of how each subset contributes to the pathogenesis of psoriatic disease.

\section{THE CUTANEOUS $\gamma \delta$ T CELL COMPARTMENT}

Of the innate $\mathrm{T}$ lymphocytes in the skin, $\gamma \delta \mathrm{T}$ cells, defined by expression of gamma $(\gamma)$ and delta ( $\delta$ ) TCR subunits, are the most studied. Their innate classification comes from two main characteristics: first, the repertoire of $\gamma$ and $\delta$ chains possess less diversity than their more classical $\alpha \beta$ TCR counterparts. Second, $\gamma \delta \mathrm{T}$ cells do not require TCR engagement in order to expand and exert their effector functions. Rather, cytokines alone are sufficient to endow $\gamma \delta \mathrm{T}$ cells with cytotoxic and cytokine-producing ability (10).

In mice, $\gamma \delta \mathrm{T}$ are usually distinguished based on the $\gamma$ chain expression. It is worth mentioning that two nomenclatures are often used but rarely specified in the literature, namely the Heilig and Tonegawa vs. the Garman classification. In this review, we will use the Heilig and Tonegawa nomenclature only, which includes the $\mathrm{V} \gamma 1-\mathrm{V} \gamma 7$ subtypes (11). Each subtype has a propensity to localize to specific organs as well as exert unique effector functions. Their development and migration to the epithelial tissues starts during fetal life (12-14) with consecutive waves associated with different $\gamma \delta \mathrm{T}$ subsets migrating from the thymus to their specific tissue $(10,15)$. From day E13, the $\mathrm{V} \gamma 5$ subtype is produced in the thymus and migrates to the epidermis (Figure 1). $\mathrm{V} \gamma 5 \gamma \delta \mathrm{T}$ cell development is exclusively fetal and occurs only in mice. These cells are called dendritic epithelial $\mathrm{T}$ cells (DETC) due to their morphology, are nonmigratory and are maintained by self-renewal $(16,17)$. As DETC seem to be most relevant for maintaining skin homeostasis and wound repair and have been reviewed extensively elsewhere, we will not be discussing this subset further. On the other hand, $\mathrm{V} \gamma 4$ and $\mathrm{V} \gamma 6$ subtypes constitute the dermal $\gamma \delta \mathrm{T}$ cell compartment (Figure 1). Unlike DETCS, dermal $\gamma \delta \mathrm{T}$ cells are motile with ${\mathrm{V} \gamma 6^{+}}^{+}$cells seeding the dermis during fetal life and $\mathrm{V} \gamma 4^{+}$cell recruitment limited to the first days of life (18). Accordingly, the dermal $\gamma \delta \mathrm{T}$ cell compartment can be replenished after irradiation, but only if neonatal thymocytes are transferred (19).

$\mathrm{V} \gamma$ usage is also associated with a specific effector function profile. In fact, $\gamma \delta \mathrm{T}$ cells can be largely defined based on their expression of lineage-restricted transcription factors and effector functions. The most prominent subsets include IFN $\gamma$ $(\gamma \delta 1)$ and IL-17 producing $\gamma \delta \mathrm{T}$ cells $(\gamma \delta 17)$ that rely on the transcription factors T-bet and ROR $\gamma \mathrm{t}$, respectively, for their differentiation (20). Interestingly, however, $\gamma \delta \mathrm{T}$ cell effector functions are uniquely imprinted in the thymus where SOX13 drives $\gamma \delta \mathrm{T}$ cell lineage commitment and subsequent TCR dependent and independent mechanisms that dictate effector functions (21). For example, CD27 is a thymic determinant of $\gamma \delta$ $\mathrm{T}$ cell fate by promoting $\gamma \delta 1$ over $\gamma \delta 17$ cells and inducing IFN $\gamma$ associated genes (22). Additionally, strong TCR engagement favors IFN $\gamma$-producing $\gamma \delta \mathrm{T}$ development (23) while limiting $\gamma \delta 17$ development (24). As a result, IFN $\gamma$ and IL-17-producing $\gamma \delta \mathrm{T}$ subsets can be identified on the basis of CD27 and CCR6 expression, amongst other markers $(22,25)$. Dermal ${\mathrm{V} \gamma 4^{+}}^{+}$and $\mathrm{V} \gamma 6+\gamma \delta \mathrm{T}$ cells express several hallmarks similar to Th17 cells including ROR $\gamma \mathrm{t}$, IL-7R, CCR6, and IL-23R expression as well as ability to produce IL-17 $(19,26)$. They can be stimulated by IL-23, which leads to their expansion and IL17 production (26) (Figure 1). Dermal $\gamma \delta \mathrm{T}$ cells have been associated with immunosurveillance functions. In the context of mycobacterial infections, they have been shown to be the dominant source of IL-17 and their absence was correlated with diminished immune response to BCG immunization (27). Furthermore, IL-17 production by dermal $\gamma \delta \mathrm{T}$ can be stimulated by various microbe-derived products (26), further emphasizing their immune sentinel role. As $\mathrm{V} \gamma 6^{+}$cells are rarely found in secondary lymphoid organs, MacKenzie et al. suggested that this subset might have specifically evolved for immunosurveillance of non-lymphoid tissues while the more migratory, lymphoid organ-skewed $\mathrm{V} \gamma 4$ subset might serve as a pool that is rapidly mobilized to barrier sites following challenge (28).

In humans, $\gamma \delta \mathrm{T}$ cells are usually distinguished based on $\delta$ chain expression including $\mathrm{V} \delta 1, \mathrm{~V} \delta 2$, and $\mathrm{V} \delta 3$ (i.e., $\mathrm{V} \delta 1-\mathrm{V} \delta 2-)$ subtypes. V $\delta 1$ cells seed barrier tissues while V $\delta 2$ and $\mathrm{V} \delta 3$ are observed in the blood of healthy patients (29). Similar to murine $\gamma \delta \mathrm{T}$ cells, human $\gamma \delta \mathrm{T}$ cells are potent cytokine-producing cells, but the regulatory mechanisms are less understood. Unlike murine $\gamma \delta \mathrm{T}$ cells, human $\gamma \delta \mathrm{T}$ cells are more dependent on TCR engagement for activation and appear to produce a greater diversity of effector cytokines. For example, human $\gamma \delta 17$ cell differentiation, which likely occurs in the periphery since they are absent from the human mature thymus (30), requires IL-23 and TCR activation. Furthermore, $\mathrm{V} \gamma 9 \mathrm{~V} \delta 2$ cells that represent the majority of the $\mathrm{V} \delta 2$ subset, exhibit remarkable heterogeneity in term of surface markers and cytokine production. These plastic cells are able to produce IFN $\gamma$, IL-4, or IL-17, which contrasts with murine $\gamma \delta \mathrm{T}$ cell commitment (31).

As opposed to mice, human $\gamma \delta \mathrm{T}$ cells are rare in the skin with $\mathrm{V} \delta 1$-expressing cells being the dominant subtype observed in healthy skin, mainly in the dermis. With the help of $\alpha \beta \mathrm{T}$ cells (16), $\mathrm{V} \delta 1$ seem to recapitulate the role of DETC given that they present a restricted repertoire (32), can be observed in the epidermis, produce keratinocyte growth factors and exert anti-tumor activity $(31,33) . \mathrm{V} \delta 1^{+}$cells are also usually associated with IFN $\gamma$ production and a cytotoxic profile (34). Notably, human dermis-derived $\gamma \delta \mathrm{T}$ cells have been shown to produce IL-17A. In fact, Cai et al. found IL-17producing $\gamma \delta \mathrm{T}$ cells to be enriched in psoriatic skin lesions. However, the full repertoire of cutaneous $\gamma \delta \mathrm{T}$ cells has yet to be investigated (26). 


\section{$\gamma \delta$ T Cells Are Major Contributors to Murine Psoriasiform Inflammation and Implicated in Human Disease}

Two mouse models of cutaneous inflammation are most commonly used to study the mechanisms underlying psoriasiform inflammation. The imiquimod (IMQ) model that consists of topically applying a TLR7/8 agonist emulsified in a cream or intradermal injection of recombinant IL-23 $(5,35)$. Both approaches lead to epidermal hyperplasia, parakeratosis, and expansion of rete ridges, all features of psoriasiform inflammation (36). These preclinical models have been shown to depend on the presence of IL-17 for fulminant inflammation and motivated clinical trials the development of neutralizing antibodies targeting IL-23, IL-17A, or IL-17RA (the receptor for both IL-17A and IL-17F) $(5-7,26)$. The incredible clinical success of these biologics has validated these models and led to further investigation into the cell types driving IMQ and IL-23-induced inflammation $(6,7)$. Importantly, both models revealed decreased inflammation and psoriasiform symptoms inflammation in mice genetically lacking $\gamma \delta \mathrm{T}$ cells $\left(\mathrm{TCR} \delta^{-/-}\right)$ compared to mice deficient in $\alpha \beta \mathrm{T}$ cells $\left(\mathrm{TCR} \alpha^{-/-}\right)$mice $(26,37)$. Importantly, TCR $\delta^{-/-}$mice reconstituted with $\mathrm{V} \gamma 4$ and $\mathrm{V} \gamma 6$ subpopulations restored disease susceptibility (18). Similarly, selective depletion of $\mathrm{V} \gamma 6^{+}$or $\mathrm{V} \gamma 4^{+} \gamma \delta \mathrm{T}$ cells using antibody-mediated or genetic depletion approaches indicate that both subsets are necessary and sufficient for IMQ-induced inflammation $(38,39)$. Interestingly, $\mathrm{V} \gamma 4^{+} \gamma \delta \mathrm{T}$ cells have been shown to have memory-like capacity. Indeed, two papers have demonstrated that this $\gamma \delta \mathrm{T}$ cell subset persists in the skin after termination of IMQ treatment and exhibits classical features of memory cells upon secondary IMQ challenge (i.e., a more rapid response with greater magnitude) in the same area or even distant sites $(40,41)$. Ramirez-Valle et al. further demonstrated that the migration and recruitment to distant sites was mediated via CCR2 signaling (41). They showed that IMQ-activated $\mathrm{V} \gamma 4^{+} \mathrm{T}$ cells expressed less CCR6 than unchallenged $\gamma \delta$ T cells and that the former subset demonstrated increased responsiveness to IL-1. Downregulation of CCR6 was unexpected as it was previously shown that both models of psoriasis induce CCL20 (42), the chemokine recognized by CCR6, and that a CCL20/CCR6 axis was essential for disease progression $(38,43)$ (Figure 1). Induction of CCL20 leads to dermal IL- $17^{+} \gamma \delta \mathrm{T}$ cell recruitment into the epidermis, exacerbating inflammation. Accordingly, an anti-CCL20 antibody treatment reduced IL-23-induced inflammation by decreasing the $\gamma \delta \mathrm{T}$ trafficking into the epidermis (42). In the latter study, the source of chemokine secretion was not identified but it has been demonstrated that IL- $1 \beta$ can stimulate keratinocyte production of CCL2 and CCL20, which might impact $\gamma \delta$ T cell recruitment (18). In addition, activated dermal $\gamma \delta$ T cells increase expression of X-linked IL-1 receptor accessory protein-like 1 (IL1RAPL1) which promotes a feedforward system inducing more IL-17 production by these cells. IL-38, a cytokine of the IL-1 family secreted by keratinocytes at steady state, is able to restrict $\gamma \delta$ T cell activity by inhibiting IL1RAPL1 on the surface of $\gamma \delta \mathrm{T}$ cells (44). Accordingly, the levels of
TABLE 1 | Cytokines produced by innate immune cells during psoriasis.

\begin{tabular}{llc}
\hline Cytokine & Cell types & References \\
\hline $\mathrm{IL}-17 \mathrm{~A}$ & $\gamma \delta \mathrm{T}$ cell, ILC3, NK cell & $(18,26,37,38,46-49)$ \\
$\mathrm{IL}-22$ & $\gamma \delta \mathrm{T}$ cell, ILC3, NK cell & $(37,47,50)$ \\
$\mathrm{IL}-25$ (IL-17E) & $\gamma \delta T$ cell & $(51)$ \\
$\mathrm{IFN} \gamma$ & NK and NKT cell & $(52-55)$ \\
TNF $\alpha$ & NK and NKT cell & $(53)$ \\
\hline
\end{tabular}

IL-38 secreted by the keratinocytes is decreased in psoriatic lesions as well as in mouse skin following IMQ treatment $(44,45)$. These results underline the loop that exacerbates psoriasis, where inflammation induces keratinocytes secretion of chemokines, which in turn triggers $\gamma \delta$ T cell recruitment. The pro-inflammatory environment leads to cytokine production by $\gamma \delta \mathrm{T}$ cells, which promotes keratinocyte hyperproliferation and epidermal thickening.

Although $\gamma \delta$ T cells are capable of cytotoxic activity, their potent cytokine production seems to play a dominant role in psoriasiform inflammation (Table 1). In the IMQ model, both IL-17 and IL-22 production by ROR $\gamma \mathrm{t}+\gamma \delta \mathrm{T}$ cells, $\mathrm{V} \gamma 4^{+}$cells in particular, is greatly increased (37) (Figure 1). Consistent with these results, IL-17R deficient mice showed reduced and delayed signs of psoriasiform inflammation such as ear thickness and erythema after IMQ treatment (56). However, disease was not completely abolished in IL-17R deficient mice and increased levels of TNF $\alpha$, IL-6, and IL-22 as well as IL-17-producing cells were observed in the skin. This demonstrates the importance of IL-17 signaling for psoriasiform inflammation, but also suggests an alternative pathway for IMQ-induced inflammation. Similarly, IMQ-induced inflammation was strongly reduced in mice with a keratinocyte-specific deletion of the IL-17 receptor (57). In another study using the IMQ model, the main producer of IL-22 was also $\gamma \delta \mathrm{T}$ cells. However, in Rag-deficient mice that lack mature T and B cells, levels of IL-22 in response to IMQ remained elevated suggesting an alternative source of cutaneous IL-22 (50). Although it was shown that, in addition to IL-17, IL-22 is required for IL-23 induced inflammation, the failure of clinical trials using anti-IL-22 antibodies have kept the focus on the effector functions of IL-17 and its associated family members. In fact, a recent report showed that IL-17E (better known as IL-25) signaling via IL-17RB also plays an important role in IMQ-induced psoriasiform inflammation (51). This work was recently followed up by studies demonstrating that IL-17A can signal via an alternative receptor, IL-17RD, to drive psoriasiform inflammation (58). To conclude, $\gamma \delta$ T cells are major contributors to murine psoriasiform inflammation via the production of IL17 and IL-22 (Figure 1, Table 1). The V $\gamma 4$ subtype is particularly implicated in the disease due to its quick cytokine response, migration capacities and long-lasting memory capacity.

Such as in mice, $\gamma \delta \mathrm{T}$ cells are expanded in human psoriatic skin and produce IL-17A (26) (Table 1). A population of $\mathrm{V} \gamma 9 \mathrm{~V} \delta 2^{+}$cells that express IL-17A, IFN $\gamma, \mathrm{TNF} \alpha$ and CCR6 has been specifically observed in human psoriatic lesions (59). These cells were able to activate keratinocytes and stimulate 
chemokine, cytokine and defensin production. Laggner et al. also showed that $\mathrm{V} \gamma 9 \mathrm{~V} \delta 2^{+}$cells were increased in psoriatic skin compared to healthy skin and, even more, increased in lesional skin compared to non-lesional skin of the same patients (59). In addition, $\mathrm{V} \gamma 9 \mathrm{~V} \delta 2^{+}$cells were reduced in psoriatic patient blood. Finally, they showed a negative correlation between blood levels of $\mathrm{V} \gamma 9 \mathrm{~V} \delta 2^{+}$cells and psoriasis severity. These results suggest that the $\mathrm{V} \gamma 9 \mathrm{~V} \delta 2^{+}$population is recruited from the peripheral blood to the skin where they activate keratinocytes and contribute to psoriasis development. On the other hand, it has been recently shown that the majority of IL-17A producing $\mathrm{T}$ cells observed in human psoriatic lesions are oligoclonal $\alpha \beta$ T cells and not $\gamma \delta \mathrm{T}$ cells (60). Furthermore, mast cells have been shown to produce IL-17A and IL-22 in human psoriatic plaques (61). The diverse subsets previously found to be expressing and/or producing IL17 cytokines in human psoriasis and disparate results between groups continues to fuel a controversy over the most relevant cytokine-producing cells for psoriatic disease development and progression. Longitudinal studies using large, diverse patient cohorts may help reconcile these differences.

\section{THE INNATE LYMPHOID CELL SKIN POPULATION}

ILCs are bone marrow-derived tissue-resident lymphocytes that, although arising from common lymphoid progenitors, do not express rearranged antigen-specific receptors. ILC nomenclature is largely analogous to $\mathrm{CD}^{+} \mathrm{T}$ helper effector cell subsets: ILC1s express the transcription factor T-bet and secrete IFN $\gamma$, ILC2s express GATA3 and produce the Th2 cytokines IL-5 and IL-13 and ILC3s express ROR $\gamma \mathrm{t}$ and secrete IL-17 and IL-22. Although ILCs are thought to be largely tissue-resident cells (62), ILCs have been detected in the circulation that express high levels of cutaneous leukocyte-associated antigen (CLA), a skin homing marker (63). In both mice and humans, all three groups of ILCs have been observed in the skin with ILC2s being the largest population (63-65). Furthermore, a study examining the cutaneous ILC population in mice showed that different layers of the skin are populated differentially by ILCs: the epidermis is mainly populated by ILC3s, the subcutaneous layer is populated by ILC2s and the dermis contains both ILC2s and ILC3s (66) (Figure 1). However, the signals that result in the differential homing of ILCs in the skin and whether this is representative of human ILC populations is not completely understood. ILC1s, although present in the skin, are a rare population with unknown functions. Although sharing several features with natural killer (NK) cells, ILC1s do not exert cytotoxic activity-lack perforin and granzyme expression-and do not express traditional NK cell antigens such as CD56, CD16, or CD94. However, the cytokine profile of ILC1s, most notably IFN $\gamma$, resembles NK cells and has been shown to play a role in the protection against intracellular pathogens $(62,67,68)$. As ILC1s are thought to contribute to Crohn's disease and inflammation in a mouse model of colitis $(69,70)$, they could potentially play similar roles in the skin both in terms of protection as well as autoimmune-like pathology, however this has not been thoroughly investigated. ILC2s on the other hand are much more common in the skin and are thought to play a role in maintaining skin homeostasis. For example, ILC2s have been shown to promote wound healing in the skin through the production of IL-13 $(71,72)$. Skin-resident ILC2s can also produce high levels of amphiregulin, a molecule regulating wound healing (73). In dermatitis, amphiregulin has been shown to play a role in wound healing by acting as an epidermal growth factor receptor (EGFR) ligand (74). However, other evidence indicates the involvement of ILC2s in allergic-type or type 2 inflammation of the skin, namely atopic dermatitis likely through dysregulated production of type 2 cytokines such as IL- 5 and IL$13(73,75,76)$. Lastly, ILC3s are one of the subtypes of immune cells in the skin capable of producing IL-17A and IL-22 and are therefore of specific interest when discussing psoriasis (Figure 1).

\section{ILC3s Are Observed in Human Psoriatic Skin and Correlate With Disease Severity}

While ILC3s seem to play a role in the development and maintenance of psoriasis, the role of ILC1 and 2 subsets is a matter of debate (Figure 1). Some groups found a reduction in ILC2 numbers in psoriatic patients (64) while others saw no difference in frequencies. Notably, different methods of tissue processing from skin biopsies in these studies may explain the differences (63-65). Given that ILC2s are known to play a role in maintaining skin homeostasis and wound healing $(71,72)$, they may also be playing a protective role during the development of psoriasis. Second, these studies did not indicate involvement of ILC1s (63-65). However, one group reported a significant increase in the number of ILC1s in psoriatic skin (77); this latter group detected the number of ILCs using imaging of whole skin whereas the other groups performed flow cytometry which may explain the difference. Since ILC1s in the gut seem to play a role in inflammatory pathologies, it is possible that ILC1s may also be paying a role in inflammatory pathologies in the skin such as psoriasis. When looking at the cells in circulation, both healthy individuals and psoriatic patients have a similar mean frequency of ILCs in total peripheral blood mononuclear cells (PBMCs) (65). However, there seems to be an overall increase of ILCs in psoriatic skin (Figure 1). This increase in ILCs is mainly due to an increase of ILC3s $(63,64,77)$. NKp44 has been associated with pro-inflammatory functions in ILC3s, its activation leading to $\mathrm{TNF} \alpha$ production (78). ILC3s in the skin of healthy patients were shown to be mainly NKp44-, whereas NKp44+ ILC3s were barely detectable in the skin and blood (63). NKp44 expression is induced in NKp44-ILC3s upon IL-1 $\beta$ and IL-23 stimulation, cytokines commonly present in psoriatic inflammation (63) (Figure 1). In psoriasis patients, the levels of NKp44 ${ }^{+}$ILC3 but not NKp44- ILC3s were increased in the blood, lesional, and non-lesional skin. Furthermore, psoriasis severity as measured by the PASI scoring system positively correlated with the number of cutaneous NKp44+ ILC3s (63-65). These data suggest that the amount of $\mathrm{NKp} 44^{+}$ILC3s in the blood or the skin can potentially be used as a biomarker for disease severity. Furthermore, ILCs in psoriatic skin were seen to be in close proximity to $\mathrm{T}$ cells, suggesting a crosstalk between ILCs and $\mathrm{T}$ cells during the development of psoriasis (77). Given the innate features of ILC3s 
and their largely tissue-resident nature, these cells may contribute to the initiation of psoriatic inflammation. Indeed, ILC3s alone were able to induce psoriasis in a human skin xenotransplant mouse model to a degree similar to $\alpha \beta$ T cells (79). Furthermore, patients with psoriatic arthritis, a disorder with similar features of psoriasis but with joint involvement, also had an increased ILC3: ILC2 ratio (80).

As mentioned above, IL-17 producing $\gamma \delta \mathrm{T}$ cells have been shown to be important drivers of IMQ-induced inflammation (81). However, it has been shown that Rag-deficient mice are still susceptible to psoriasiform inflammation via IMQ (37, 43), indicating that cells other than $\mathrm{T}$ cells play a role in the pathogenesis. Using Rag1/IL-2R deficient mice lacking $\mathrm{T}$ cells and ILC, Pantelyushin et al. showed that ROR $\gamma \mathrm{T}^{+} \gamma \delta \mathrm{T}$ cells and ROR $\gamma \mathrm{t}^{+}$ILC contribute to IMQ-induced psoriasiform inflammation (37). Furthermore, anti-TNF $\alpha$ or TNF $\alpha$ inhibitor treatment has been demonstrated to be a very effective treatment for psoriasis (82). TNF $\alpha$ plays a role in psoriasis development by synergizing with IL-23 to induce IL-17 producing cells, including ILC3s (46). Individuals undergoing successful anti$\mathrm{TNF} \alpha$ (adalimumab) treatment for psoriasis had a reduction in the number of pathogenic NKp44 ${ }^{+}$ILC3s and an increase in NKp44- ILC3s in the circulation (65), suggesting that a major role of $\mathrm{TNF} \alpha$ in the pathogenesis of psoriasis includes potentiating pathogenic ILC3s. However, it was elegantly demonstrated that $\gamma \delta 17$ were non-redundant effector cells in murine skin pathology (81). Indeed, when $\gamma \delta 17$ cells were deleted from birth, they were replaced by IL-17 producing ILC3s that promoted IMQ-induced inflammation. However, acute depletion of $\gamma \delta 17$ cells did not lead to ILC3 accumulation and mice remained resistant to psoriasiform inflammation. In summary, ILC2s appear dominant in healthy skin whereas NKp44 ${ }^{+}$ILC3s are the major ILC subset associated with psoriatic disease. Although ILC3s and $\gamma \delta 17$ cells may play overlapping roles in murine models of psoriasis, more studies are needed to discern their relative contributions to human disease.

\section{CUTANEOUS NK AND NKT CELLS}

Natural Killer (NK) cells are a group of innate immune cells with both cytotoxic and cytokine producing effector functions and have been recently classified as one of two ILC1 subsets $(83,84)$. Through germ-line encoded activating and inhibitory receptors, NK cells can respond quickly following activation, releasing pro-inflammatory cytokines particularly IFN $\gamma$, chemokines, or specialized cytotoxic granules to infected or tumor cells (85). In human and mice, there are two distinct populations of NK cells, circulating NK cells $\left(\mathrm{cNK}, \mathrm{CD} 49 \mathrm{a}^{+} \mathrm{CD} 103^{-}\right.$or $\mathrm{CD} 56^{\mathrm{dim}} \mathrm{CD} 16^{+}$ in human and $\mathrm{CD}_{4} \mathrm{a}^{-} \mathrm{DX} 5^{+}$in mice) and tissue-resident NK cells (trNK, CD49a ${ }^{-} \mathrm{CD} 103^{+}$, or $\mathrm{CD}^{2} 6^{\text {bright }} \mathrm{CD}^{-} 6^{-}$in human and $\mathrm{CD} 49 \mathrm{a}^{+} \mathrm{DX} 5^{-}$in mice) (Figure 2); both can induce cytotoxicity and produce cytokines (86-89). Murine skin is composed of both trNK cells and cNK cells (87) (Figure 2). However, the $\mathrm{cNK}$ and trNK cells do not share the same development pathways. cNK cells are derived from the bone marrow, continue their maturation in the thymus and then the spleen, tonsils and lymph nodes $(90,91)$. In mice, the transcription factors T-bet and Eomes are required for the maturation of cNK cells (92). In humans, both T-bet and Eomes are co-expressed in mature cNK cells (93). T-bet is expressed at lower levels in cytokine-producing CD56 ${ }^{\text {bright }}\left(\mathrm{CD} 56^{\text {hi }} \mathrm{CD} 16^{-}\right)$ $\mathrm{NK}$ cells than the highly cytotoxic CD56 ${ }^{\mathrm{dim}}\left(\mathrm{CD} 56^{\mathrm{lo}} \mathrm{CD} 16^{+}\right)$ NK cells, while CD56 $6^{\text {bright }} \mathrm{NK}$ cells have higher frequency of Eomes ${ }^{+}$cells than CD56 ${ }^{\mathrm{dim}} \mathrm{NK}$ cells (93), indicating that there is a gradual loss of Eomes expression during the development of CD56 ${ }^{\text {bright }}$ cells to T-bet ${ }^{\text {hi }}$ Eomes ${ }^{+}$CD56 ${ }^{\text {dim }}$ cells. trNK cells were first discovered in the murine liver, strictly require T-bet, Hobit and PLZF for their development, however do not express Eomes $(87,89)$. Murine liver trNK cells are capable of degranulation and produce similar IFN $\gamma$ levels to cNK cells. However, both the liver IFN $\gamma^{+}$and degranulating trNK cells produce TNF $\alpha$, which is rarely seen among responding cNK cells (87). Unlike mouse trNK cells, human liver trNK cells have high Eomes expression rather than T-bet (94). Of note, the features and developmental pathways of trNK cells differ from one organ to another. In the murine gut and dermis, the development of $\mathrm{NKp} 46^{+} \mathrm{CD}^{-}$trNK cells is reported to be dependent on the transcriptional factor $\mathrm{ROR} \gamma \mathrm{t}$ and $\mathrm{ROR} \gamma \mathrm{t}^{+}$trNK cells are capable of producing IL-22 (95). The origin of skin trNK cells is unclear, but murine studies show that skin trNK cells share some features with liver trNK cells, in terms of phenotype, function and developmental requirements. They are $\mathrm{CD} 49 \mathrm{a}^{+} \mathrm{DX} 5^{-}$with no Eomes expression, and their development is dependent on IL15 and IL-15R. Human $\mathrm{CD} 56^{\text {bright }} \mathrm{CD} 16^{-} \mathrm{NK}$ cells are present in the dermis at steady state and disease conditions such as psoriasis, while $\mathrm{CD} 6^{+} \mathrm{CD} 16^{+} \mathrm{cNK}$ cells are rare $(52,96,97)$. These $\mathrm{CD}_{56}{ }^{\text {bright }} \mathrm{CD} 16^{-}$dermal NK cells lack perforin and NKG2D expression but are capable of lysing melanoma cells after activation in vitro (97). Recently, studies have found IL-17 and IL22 producing NK cells in both humans and mice, which indicates the potential for NK cell participation in the development of psoriasis (47-49).

Natural Killer T (NKT) cells are present in both human and mouse skin (Figure 2). However, the composition of NKT cells is not well-defined. In human allergic contact dermatitis, for example, NKT cells range from 1.72 to $33 \%$ of the $\mathrm{T}$ lymphocyte infiltrate and in human atopic dermatitis patients, the proportion of NKT cells in $\mathrm{CD}^{+} \mathrm{T}$ cells is $\sim 5 \%(98,99)$. In murine skin, they compose $\sim 0.03 \%$ of total healthy skin cells and $\sim 0.6 \%$ of total hyperplastic skin cells (100). NKT cells are a unique hybrid between $\alpha \beta \mathrm{T}$ cells and NK cells as they coexpress an $\alpha \beta$ TCR and NK cell lineage markers. NKT cells are divided into four categories with type 1 (referred to as invariant NKT cells) being the vast majority (101). Compared to conventional $\mathrm{T}$ cells, they express a semi-invariant TCR $\alpha$ chain (V $\alpha 14-\mathrm{J} \alpha 18$ in mice and $\mathrm{V} \alpha 24-\mathrm{J} \alpha 18$ in human), which allows specific recognition of glycolipids presented on an atypical MHC Class I molecule, CD1 (102-104). $\alpha$-galactosylceramide ( $\alpha$-GalCer), a compound derived from marine sponges, has a strong CD1d binding affinity and is a potent stimulant for iNKT cells. Potential endogenous ligands of NKT cells were previously believed to be glycosphingolipids (GSLs) and phospholipids that are derived from bacterial, plant, protozoan, and mammalian 


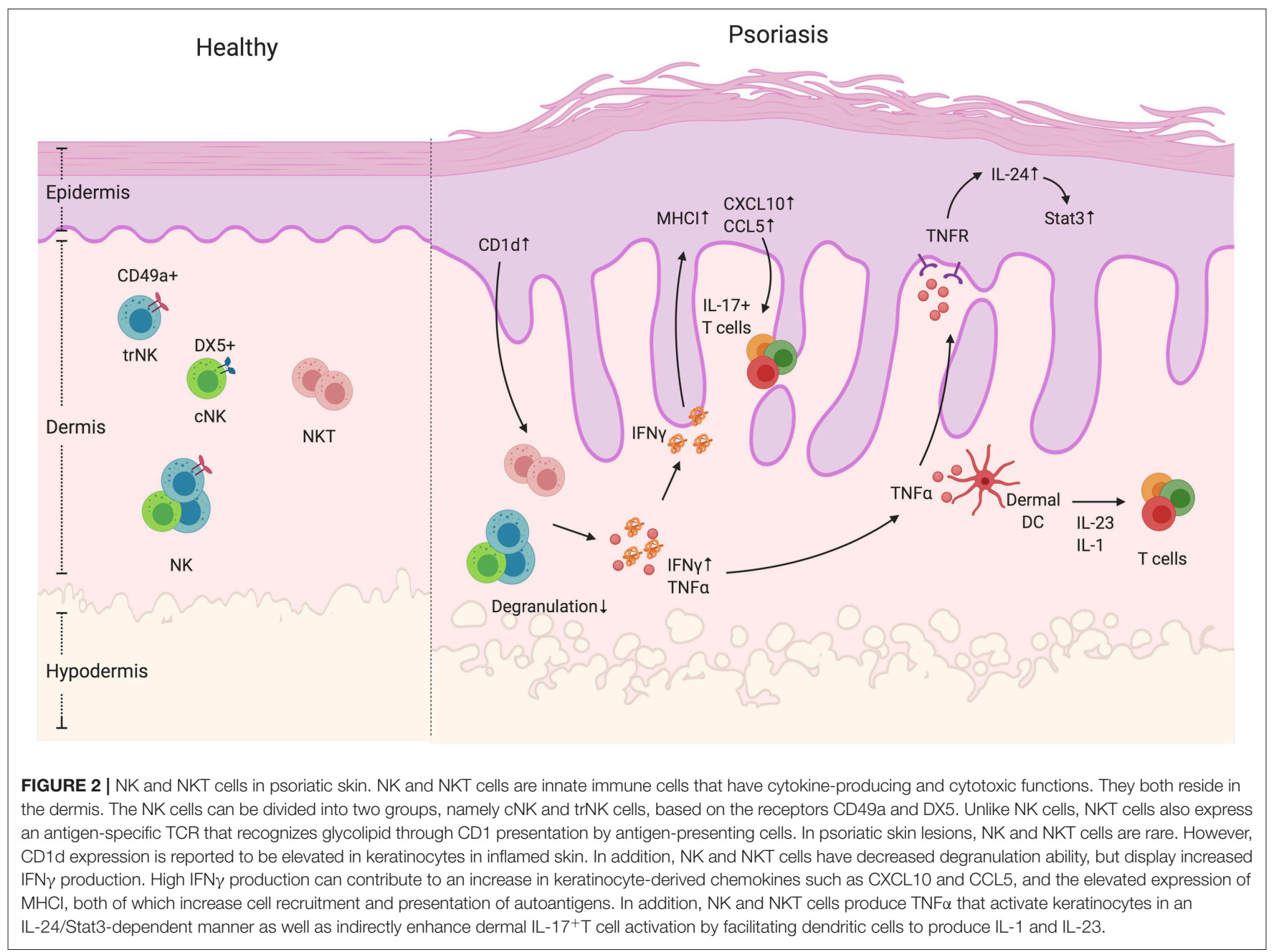

species. However, more recent studies suggest that NKT cell ligands are more diverse and not limited to GSLs $(105,106)$. Thus, the endogenous ligands of NKT cells are still being clarified. When stimulated with $\alpha$-GalCer or its analogs, NKT cells rapidly produce pro- and anti-inflammatory cytokines including IFN $\gamma$, TNF $\alpha$, IL-10, IL-4, IL-13, IL-17 and GM-CSF, and participate in the regulation of infection, autoimmunity, and tumor immunity (107). Unlike NK cells, NKT cells undergo positive and negative selection within the thymus, but emerge later in development than most other T cell subsets $(108,109)$. During the selection process, NKT cells are only selected when $\mathrm{CD} 1$ is expressed on double positive $\left(\mathrm{CD} 4^{+} \mathrm{CD} 8^{+}\right)$thymocytes, which segregates the NKT cell (CD161 low in human and NK1.1- in murine at this stage) from the conventional $\mathrm{T}$ cell developmental pathway (110-114). The transcriptional factors Ras, Mek, Fyn, and Ets1 are reported to participate in the development of murine NKT cells, and the cytokine IL-15 and its receptor IL-15R are important during NKT cell development (115-118). After selection, the immature human CD161low or murine NK1.1- NKT cells either stay in the thymus or migrate to peripheral tissues, where they undergo a maturation process with the upregulation of CD161 (human) or NK1.1 (murine) expression $(108,109)$. The transcription factor T-bet was shown to participate in the terminal maturation of NKT cells (119). Both mouse and human NKT cells can exert cytotoxicity and produce seemingly antagonistic IL-4 and IFN $\gamma$ cytokines upon TCR stimulation $(120,121)$. However, cytokine production may be developmentally regulated as mature NKT cells produce high levels of IFN $\gamma$ while IL-4 is dominantly produced by immature NKT cells $(108,109)$. Recent data showed that NKT cells can also secrete Th17-related cytokines such as IL-17A, IL-17F, and IL-22 $(107,122,123)$. A murine CD4-NK1.1- NKT cell group, which is the precursor of CD4-NK1.1 $1^{+}$NKT cell, has been found to constitutively express ROR $\gamma$ t and IL-23R and is a major source of IL-17 ${ }^{+}$NKT cells (107). In addition, $\alpha$-GalCer-activated murine NKT cells, that can express ROR $\gamma t$ and IL-17, but not IFN $\gamma$ or IL4, develop in a c-Maf dependent way. These IL- $17^{+} \mathrm{NKT}$ cells are essential for inducing neutrophil-rich airway inflammation (122). In humans, even though ROR $\gamma \mathrm{t}^{+}$T-betloPLZF- NKT cells are found in the circulating PBMCs, the IL-23R expression is almost completely absent on circulating NKT cells. These NKT cells show poor IL-17 release after IL-23 stimulation. However, TCR 
stimulation (e.g., $\alpha$-GalCer or $\alpha \mathrm{CD} 3 / \mathrm{CD} 28 \mathrm{Ab}$ ) in the presence of IL-2, IL-23, IL-1 $\beta$ and TGF $\beta 1$, NKT cells successfully produce IL-17 but not IFN $\beta$ or TNF $\alpha$ (123). Interestingly, there are more IL-23R ${ }^{+}$NKT cells in the PBMCs and joint compartment of Spondyloarthritis patients than healthy controls, showing an IL-17 signature (123), which suggests that NKT cells could participate in the development of psoriasis. Although cutaneous NKT cells are important for the anti-microbial response due to their ability to recognize the bacterial glycolipids via CD1d presentation (124), they may function differently in cutaneous diseases, a result that may depend on the microbial and/or selfantigen repertoire of the skin. It has been shown that large numbers of NKT cells can be recruited into human skin during contact dermatitis, producing mainly $\operatorname{IFN} \gamma(98,99)$ however, results in animal studies are controversial. Murine NKT cells were previously reported to suppress this response by producing IL-4 and IL-13 in response to CD1d-presented haptens (125), while it was also reported that murine NKT cells enhance the contact sensitivity reaction (126-128). Different results may be explained by the animal model studied, which shape the NKT cell cytokine repertoire. Studies have found decreased number of circulating $\mathrm{V} \alpha 24^{+} \mathrm{NK} \mathrm{T}$ cells in atopic dermatitis patients, and they produce both IL-4 and IFN $\gamma(99,129)$. NKT cells were also shown to suppress skin transplant rejection, through the production of IL-4 (130-132). To conclude, even though the proportion of NK and NKT cells is rare, they do participate in cutaneous immunity through diverse effector programs.

\section{NK and NKT Cells Are Rare in Psoriatic Skin}

The role of NK and NKT cells in psoriasis development is not clear. Even though studies showing involvement of NK cells in psoriasis are rare, NK cells have been shown to be present in psoriatic skin. Human studies show that NK cells are recruited in psoriatic plaques, particularly in the dermis $(52,133)$ (Figure 2). The psoriatic lesion-isolated NK cells exhibited low degranulation ability. However, their cytokine-producing ability is dependent on the source of NK cells $(52,53)$. Ottaviani et al. observed higher IFN $\gamma$ production by $\mathrm{NK}$ cells isolated from psoriatic lesions and showed that IFN $\gamma$ was able to induce keratinocyte chemokine production (such as CXCL10 and CCL5) and MHC-I expression (52) (Figure 2, Table 1). Consistent with the human data, mice treated with IMQ had increased NK1.1 ${ }^{+}$ cells in the skin, which suggests that either NK or NKT cells were recruited into the skin during psoriasiform inflammation (134). Another study showed that NK cells from PBMCs of patients with psoriasis vulgaris have reduced cytotoxicity and lower levels of pro-inflammatory cytokines IFN $\gamma$ and TNF $\alpha$ (53). However, questions remain about NK cells in the context of psoriasis. Psoriasis was initially thought to be a IFN $\gamma$ related disease but more recent studies-and the success of biologics targeting the IL-17 pathway-indicate a more dominant role for TNF $\alpha$ and IL-17 driven disease $(1,135,136)$. As suggested above, $\mathrm{TNF} \alpha$ and its associated receptors have been reported to be elevated in psoriatic lesions compared to non-lesional skin and TNF-R is abundantly expressed by keratinocytes $(137,138)$.
It has been reported that $\mathrm{TNF} \alpha$ signaling is involved in IL-24induced psoriasis like inflammation in mice (139). In addition, both $\mathrm{TNF} \alpha$ inhibitors and blocking antibodies show efficacy in alleviating psoriatic arthritis symptoms (140). Since both IFN $\gamma^{+}$and degranulating skin trNK cells produce $\mathrm{TNF} \alpha$ (87), it is possible that skin NK cells participate in the progression of psoriasis by the production of TNF $\alpha$ rather than IFN $\gamma$. To address this question, TNF $\alpha$ production by NK cells in the skin of healthy control and psoriasis patients needs to be addressed. To date, there is no direct link between IL-17 signaling and NK cell function in psoriasis. However, NK cells have been implicated in protection from oral and dermal Candidiasis infections that requires IL-23 and IL-17 signaling $(8,141,142)$. Whether NK cells participate in psoriasis via IL-17 signaling needs to be further explored. A concern about human NK cell studies is that CD56 is routinely used as a marker for NK cells, however, CD56 is also found on human IL-17 and IL-22-producing ILCs $(47,143,144)$. Therefore, these studies do not exclude other CD56 ${ }^{+}$ILCs in the involvement in psoriasis.

The NKT frequency within the psoriatic lesions is very low$<0.1 \%$-indicating that they are an unlikely determinant of psoriasis development (52). However, Nickoloff et al. showed that in vitro co-culture of NKT cells with CD1d-overexpressing keratinocytes is able to directly induce NKT production of IFN $\gamma$ and IL-13. In addition, the in vivo injection of psoriasis lesionderived NKT cells into the pre-psoriatic engrafted skin in SCID mice could successfully induce psoriatic plaques (54), indicating a potential role of NKT cells in the psoriasis progression. Of note, the previous attempts to use IFN $\gamma^{+} \mathrm{CD}^{+} / \mathrm{CD}^{+} \mathrm{T}$ cell lines to induce psoriasis using this experimental approach were unsuccessful (145). This effect may be due to increased skininfiltrating CD8 T cells (54), which predominantly generate IL-17 responses in human psoriasis lesions (146). This result is consistent with a human study showing that in psoriatic lesions, CD1d expression was highly enhanced in keratinocytes, which may activate the NKT cells to produce more IFN $\gamma$, thus contributing to the progression of psoriasis (55) (Figure 2). However, as previously mentioned, IL-17, TNF $\alpha$, and GMCSF production by NKT cells should also be also examined. Finally, the frequency of NKT cells expressing inhibitory receptors rather than activating receptors $\left(\mathrm{CD}_{158 \mathrm{~b}^{+}}\right.$and/or CD94/NKG2A ${ }^{+}$) was elevated in the circulation of psoriasis patients and correlated with disease severity (147). To conclude, even though they are rare in psoriatic lesions, NKT might contribute to plaque development by IFN $\gamma$ production, thus recruiting more immune cells such as IL-17 producing T cells to exacerbate the disease progression.

\section{CONCLUSION}

$\gamma \delta \mathrm{T}$, ILC, NK, and NKT cells have all been shown to be increased in psoriasiform inflammation in humans and mice. Consistently, evidence suggests a correlation between disease severity and peripheral blood levels of $\gamma \delta$ T, ILCs, and NKT. In addition, murine models lacking $\gamma \delta \mathrm{T}$ and/or ILCs demonstrated their essential role in psoriasiform inflammation 
development suggesting that NK and NKT cells likely play a more subtle role, a finding largely supported by studies of plaque psoriasis in humans. One fundamental characteristic of innate cells is their ability to respond rapidly and produce comparatively large amounts of inflammatory mediators in the absence of cognate antigen. Consistent with these traits, $\gamma \delta \mathrm{T}$, ILCs, and NKT are all able to produce cytokines that have established pathogenicity in psoriasis. These results suggest that despite the relative rarity of these populations in psoriatic lesions, they may be more amenable to nonspecific dysregulation with important consequences for disease. Interestingly, the emerging concept of "innate memory" (148), as implicated in $\gamma \delta \mathrm{T}$ cell-driven psoriasiform inflammation,

\section{REFERENCES}

1. Lowes MA, Suarez-Farinas M, Krueger JG. Immunology of psoriasis. Annu Rev Immunol. (2014) 32:227-55. doi: 10.1146/annurev-immunol-032713-120225

2. Dika E, Bardazzi F, Balestri R, Maibach HI. Environmental factors and psoriasis. Curr Probl Dermatol. (2007) 35:118-35. doi: 10.1159/000106419

3. Chandra A, Ray A, Senapati S, Chatterjee R. Genetic and epigenetic basis of psoriasis pathogenesis. Mol Immunol. (2015) 64:313-23. doi: 10.1016/j.molimm.2014.12.014

4. Takeshita J, Grewal S, Langan SM, Mehta NN, Ogdie A, Van Voorhees AS, et al. Psoriasis and comorbid diseases: epidemiology. J Am Acad Dermatol. (2017) 76:377-90. doi: 10.1016/j.jaad.2016.07.064

5. van der Fits L, Mourits S, Voerman JS, Kant M, Boon L, Laman JD, et al. Imiquimod-induced psoriasis-like skin inflammation in mice is mediated via the IL-23/IL-17 axis. J Immunol. (2009) 182:5836-45. doi: 10.4049/jimmunol.0802999

6. Hawkes JE, Chan TC, Krueger JG. Psoriasis pathogenesis and the development of novel targeted immune therapies. J Allergy Clin Immunol. (2017) 140:645-53. doi: 10.1016/j.jaci.2017.07.004

7. Conrad C, Gilliet M. Psoriasis: from pathogenesis to targeted therapies. Clin Rev Allergy Immunol. (2018) 54:102-13. doi: 10.1007/s12016-018-8668-1

8. Conti HR, Shen F, Nayyar N, Stocum E, Sun JN, Lindemann MJ, et al. Th17 cells and IL-17 receptor signaling are essential for mucosal host defense against oral candidiasis. J Exp Med. (2009) 206:299-311. doi: 10.1084/jem.20081463

9. Cho JS, Pietras EM, Garcia NC, Ramos RI, Farzam DM, Monroe HR, et al. IL-17 is essential for host defense against cutaneous Staphylococcus aureus infection in mice. J Clin Invest. (2010) 120:1762-73. doi: 10.1172/JCI40891

10. Carding SR, Egan PJ.Gammadelta $T$ cells: functional plasticity and heterogeneity. Nat rev Immunol. (2002) 2:336-45. doi: 10.1038/nri797

11. Heilig JS, Tonegawa S. Diversity of murine gamma genes and expression in fetal and adult T lymphocytes. Nature. (1986) 322:836-40. doi: $10.1038 / 322836 \mathrm{a} 0$

12. Asarnow DM, Kuziel WA, Bonyhadi M, Tigelaar RE, Tucker PW, Allison JP. Limited diversity of gamma delta antigen receptor genes of Thy-1+ dendritic epidermal cells. Cell. (1988) 55:837-47. doi: 10.1016/0092-8674(88)90139-0

13. Havran WL, Allison JP. Developmentally ordered appearance of thymocytes expressing different T-cell antigen receptors. Nature. (1988) 335:443-5. doi: $10.1038 / 335443 \mathrm{a} 0$

14. Itohara S, Tonegawa S. Selection of gamma delta T cells with canonical T-cell antigen receptors in fetal thymus. Proc Natl Acad Sci USA. (1990) 87:7935-8. doi: 10.1073/pnas.87.20.7935

15. Dunon D, Courtois D, Vainio O, Six A, Chen CH, Cooper MD, et al. Ontogeny of the immune system: gamma/delta and alpha/beta $\mathrm{T}$ cells migrate from thymus to the periphery in alternating waves. J Exp Med. (1997) 186:977-88. doi: 10.1084/jem.186.7.977 increases the complexity of these unique leukocytes and raises new questions about their roles in complex diseases such as psoriasis.

\section{AUTHOR CONTRIBUTIONS}

$\mathrm{HZ}$ and $\mathrm{BT}$ wrote the manuscript. BP and IK determined the topic and wrote the manuscript.

\section{FUNDING}

Support for this publication is provided by the Canadian Institutes of Health Research, fund PJT-148552.

16. Nielsen MM, Witherden DA, Havran WL. gammadelta T cells in homeostasis and host defence of epithelial barrier tissues. Nat Rev Immunol. (2017) 17:733-45. doi: 10.1038/nri.2017.101

17. Gentek R, Ghigo C, Hoeffel G, Jorquera A, Msallam R, Wienert S, et al. Epidermal gammadelta $\mathrm{T}$ cells originate from yolk sac hematopoiesis and clonally self-renew in the adult. J Exp Med. (2018) 215:2994-3005. doi: 10.1084/jem.20181206

18. Cai Y, Xue F, Fleming C, Yang J, Ding C, Ma Y, et al. Differential developmental requirement and peripheral regulation for dermal Vgamma4 and Vgamma6T17 cells in health and inflammation. Nat Commun. (2014) 5:39-86. doi: 10.1038/ncomms4986

19. Gray EE, Suzuki K, Cyster JG. Cutting edge: identification of a motile IL-17producing gammadelta $\mathrm{T}$ cell population in the dermis. J Immunol. (2011) 186:6091-5. doi: 10.4049/jimmunol.1100427

20. Barros-Martins J, Schmolka N, Fontinha D, Pires de Miranda M, Simas JP Brok I, et al. Effector gammadelta $\mathrm{T}$ cell differentiation relies on master but not auxiliary Th cell transcription factors. J Immunol. (2016) 196:3642-52. doi: 10.4049/jimmunol.1501921

21. Melichar HJ, Narayan K, Der SD, Hiraoka Y, Gardiol N, Jeannet $\mathrm{G}$, et al. Regulation of gammadelta versus alphabeta $\mathrm{T}$ lymphocyte differentiation by the transcription factor SOX13. Science. (2007) 315:230-3. doi: 10.1126/science.1135344

22. Ribot JC, deBarros A, Pang DJ, Neves JF, Peperzak V, Roberts SJ, et al. CD27 is a thymic determinant of the balance between interferon-gamma- and interleukin 17-producing gammadelta T cell subsets. Nat Immunol. (2009) 10:427-36. doi: 10.1038/ni.1717

23. Jensen KD, Su X, Shin S, Li L, Youssef S, Yamasaki S, et al. Thymic selection determines gammadelta $\mathrm{T}$ cell effector fate: antigen-naive cells make interleukin-17 and antigen-experienced cells make interferon gamma. Immunity. (2008) 29:90-100. doi: 10.1016/j.immuni.2008.04.022

24. Sumaria N, Grandjean CL, Silva-Santos B, Pennington DJ. Strong TCRgammadelta signaling prohibits thymic development of IL17A-secreting gammadelta $\mathrm{T}$ cells. Cell Rep. (2017) 19:2469-76. doi: 10.1016/j.celrep.2017.05.071

25. Haas JD, González FH, Schmitz S, Chennupati V, Föhse L, Kremmer E, et al. CCR6 and NK1.1 distinguish between IL-17A and IFN-gammaproducing gammadelta effector T cells. Eur J Immunol. (2009) 39:3488-97. doi: 10.1002/eji.200939922

26. Cai Y, Shen X, Ding C, Qi C, Li K, Li X, et al. Pivotal role of dermal IL17-producing gammadelta $\mathrm{T}$ cells in skin inflammation. Immunity. (2011) 35:596-610. doi: 10.1016/j.immuni.2011.08.001

27. Sumaria N, Roediger B, Ng LG, Qin J, Pinto R, Cavanagh LL, et al. Cutaneous immunosurveillance by self-renewing dermal gammadelta T cells. J Exp Med. (2011) 208:505-8. doi: 10.1084/jem.20101824

28. McKenzie DR, Comerford I, Silva-Santos B, McColl SR. The emerging complexity of gammadeltaT17 cells. Front Immunol. (2018) 9:796. doi: 10.3389 /fimmu.2018.00796 
29. Cruz MS, Diamond A, Russell A, Jameson JM. Human alphabeta and gammadelta T cells in skin immunity and disease. Front Immunol. (2018) 9:1304. doi: 10.3389/fimmu.2018.01304

30. Ribot JC, Ribeiro ST, Correia DV, Sousa AE, Silva-Santos B. Human gammadelta thymocytes are functionally immature and differentiate into cytotoxic type 1 effector T cells upon IL-2/IL-15 signaling. J Immunol. (2014) 192:2237-43. doi: 10.4049/jimmunol.1303119

31. Pang DJ, Neves JF, Sumaria N, Pennington DJ. Understanding the complexity of gammadelta T-cell subsets in mouse and human. Immunology. (2012) 136:283-90. doi: 10.1111/j.1365-2567.2012.03582.x

32. Holtmeier W, Pfänder M, Hennemann A, Zollner TM, Kaufmann R, Caspary WF. The TCR-delta repertoire in normal human skin is restricted and distinct from the TCR-delta repertoire in the peripheral blood. I Invest Dermatol. (2001) 116:275-80. doi: 10.1046/j.1523-1747.2001.01250.x

33. Toulon A, Breton L, Taylor KR, Tenenhaus M, Bhavsar D, Lanigan C, et al. A role for human skin-resident T cells in wound healing. J Exp Med. (2009) 206:743-50. doi: 10.1084/jem.20081787

34. Deusch K, Lüling F, Reich K, Classen M, Wagner H, Pfeffer K. A major fraction of human intraepithelial lymphocytes simultaneously expresses the gamma/delta T cell receptor, the CD8 accessory molecule and preferentially uses the V delta 1 gene segment. Eur J Immunol. (1991) 21:1053-9. doi: 10.1002/eji.1830210429

35. Zheng Y, Danilenko DM, Valdez P, Kasman I, Eastham-Anderson $\mathrm{J}, \mathrm{Wu} \mathrm{J}$, et al. Interleukin-22, a $\mathrm{T}(\mathrm{H}) 17$ cytokine, mediates IL-23induced dermal inflammation and acanthosis. Nature. (2007) 445:648-51. doi: $10.1038 /$ nature 05505

36. Wagner EF, Schonthaler HB, Guinea-Viniegra J, Tschachler E. Psoriasis: what we have learned from mouse models. Nat Rev Rheumatol. (2010) 6:704-4. doi: $10.1038 /$ nrrheum.2010.157

37. Pantelyushin S, Haak S, Ingold B, Kulig P, Heppner FL, Navarini AA, et al. Rorgammat+ innate lymphocytes and gammadelta $\mathrm{T}$ cells initiate psoriasiform plaque formation in mice. J Clin Invest. (2012) 122:2252-6. doi: 10.1172/JCI61862

38. Gray EE, Ramírez-Valle F, Xu Y, Wu S, Wu Z, Karjalainen KE, et al. Deficiency in IL-17-committed Vgamma4(+) gammadelta $\mathrm{T}$ cells in a spontaneous Sox13-mutant CD45.1(+) congenic mouse substrain provides protection from dermatitis. Nat Immunol. (2013) 14:584-92. doi: 10.1038/ni.2585

39. Hatano S, Tun X, Noguchi N, Yue D, Yamada H, Sun X, et al. Development of a new monoclonal antibody specific to mouse Vgamma6 chain. Life Sci Alliance. (2019) 2:e201900363. doi: 10.26508/lsa.201900363

40. Hartwig T, Pantelyushin S, Croxford AL, Kulig P, Becher B. Dermal IL-17producing gammadelta T cells establish long-lived memory in the skin. Eur J Immunol. (2015) 45:3022-33. doi: 10.1002/eji.201545883

41. Ramírez-Valle F, Gray EE, Cyster JG. Inflammation induces dermal Vgamma4+ gammadeltaT17 memory-like cells that travel to distant skin and accelerate secondary IL-17-driven responses. Proc Natl Acad Sci USA. (2015) 112:8046-51. doi: 10.1073/pnas.1508990112

42. Mabuchi T, Singh TP, Takekoshi T, Jia GF, Wu X, Kao MC, et al. CCR6 is required for epidermal trafficking of gammadelta-T cells in an IL-23-induced model of psoriasiform dermatitis. J Invest Dermatol. (2013) 133:164-71. doi: 10.1038/jid.2012.260

43. Hedrick MN, Lonsdorf AS, Shirakawa AK, Richard Lee CC, Liao F, Singh SP, et al. CCR6 is required for IL-23-induced psoriasis-like inflammation in mice. J Clin Invest. (2009) 119:2317-29. doi: 10.1172/JCI37378

44. Han Y, Mora J, Huard A, da Silva P, Wiechmann S, Putyrski $\mathrm{M}$, et al. IL-38 ameliorates skin inflammation and limits IL-17 production from gammadelta T cells. Cell Rep. (2019) 27:835-46.e835. doi: 10.1016/j.celrep.2019.03.082

45. Boutet MA, Bart G, Penhoat M, Amiaud J, Brulin B, Charrier C, et al. Distinct expression of interleukin (IL)-36alpha, beta and gamma, their antagonist IL36Ra and IL-38 in psoriasis, rheumatoid arthritis and Crohn's disease. Clin Exp Immunol. (2016) 184:159-73. doi: 10.1111/cei.12761

46. Powell N, Walker AW, Stolarczyk E, Canavan JB, Gökmen MR, Marks $\mathrm{E}$, et al. The transcription factor T-bet regulates intestinal inflammation mediated by interleukin-7 receptor+ innate lymphoid cells. Immunity. (2012) 37:674-84. doi: 10.1016/j.immuni.2012.09.008
47. Cella M, Fuchs A, Vermi W, Facchetti F, Otero K, Lennerz JK, et al. A human natural killer cell subset provides an innate source of IL22 for mucosal immunity. Nature. (2009) 457:722-5. doi: 10.1038/nature 07537

48. Lunding LP, Webering S, Vock C, Behrends J, Wagner C, Hölscher C, et al. Poly(inosinic-cytidylic) acid-triggered exacerbation of experimental asthma depends on IL-17A produced by NK cells. J Immunol. (2015) 194:5615-25. doi: 10.4049/jimmunol.1402529

49. Chowdhury AC, Chaurasia S, Mishra SK, Aggarwal A, Misra R. IL-17 and IFN-gamma producing NK and gammadelta-T cells are preferentially expanded in synovial fluid of patients with reactive arthritis and undifferentiated spondyloarthritis. Clin Immunol. (2017) 183:207-12. doi: 10.1016/j.clim.2017.03.016

50. Van Belle AB, de Heusch M, Lemaire MM, Hendrickx E, Warnier G, Dunussi-Joannopoulos K, et al. IL-22 is required for imiquimod-induced psoriasiform skin inflammation in mice. J Immunol. (2012) 188:462-9. doi: 10.4049/jimmunol.1102224

51. Xu M, Lu H, Lee YH, Wu Y, Liu K, Shi Y, et al. An interleukin25-mediated autoregulatory circuit in keratinocytes plays a pivotal role in psoriatic skin inflammation. Immunity. (2018) 48:787-98.e784. doi: 10.1016/j.immuni.2018.03.019

52. Ottaviani C, Nasorri F, Bedini C, de Pità O, Girolomoni G, Cavani A. CD56brightCD16(-) NK cells accumulate in psoriatic skin in response to CXCL10 and CCL5 and exacerbate skin inflammation. Eur J Immunol. (2006) 36:118-28. doi: 10.1002/eji.200 535243

53. Dunphy SE, Sweeney CM, Kelly G, Tobin AM, Kirby B, Gardiner CM. Natural killer cells from psoriasis vulgaris patients have reduced levels of cytotoxicity associated degranulation and cytokine production. Clin Immunol. (2017) 177:43-9. doi: 10.1016/j.clim.2015.10.004

54. Nickoloff BJ, Bonish B, Huang BB, Porcelli SA. Characterization of a $\mathrm{T}$ cell line bearing natural killer receptors and capable of creating psoriasis in a SCID mouse model system. J Dermatol Sci. (2000) 24:212-5. doi: 10.1016/S0923-1811(00)00120-1

55. Bonish B, Jullien D, Dutronc Y, Huang BB, Modlin R, Spada FM, et al. Overexpression of CD1d by keratinocytes in psoriasis and CD1d-dependent IFN-gamma production by NK-T cells. J Immunol. (2000) 165:4076-85. doi: 10.4049/jimmunol.165.7.4076

56. El Malki K, Karbach SH, Huppert J, Zayoud M, Reissig S, Schüler R, et al. An alternative pathway of imiquimod-induced psoriasis-like skin inflammation in the absence of interleukin-17 receptor a signaling. J Invest Dermatol. (2013) 133:441-51. doi: 10.1038/jid.2012.318

57. Moos S, Mohebiany AN, Waisman A, Kurschus FC. Imiquimod-induced psoriasis in mice depends on the IL-17 signaling of keratinocytes. J Invest Dermatol. (2019) 139:1110-7. doi: 10.1016/j.jid.2019.01.006

58. Su Y, Huang J, Zhao X, Lu H, Wang W, Yang XO, et al. Interleukin-17 receptor $\mathrm{D}$ constitutes an alternative receptor for interleukin-17A important in psoriasis-like skin inflammation. Sci Immunol. (2019) 4:eaau9657. doi: 10.1126/sciimmunol.aau9657

59. Laggner U, Di Meglio P, Perera GK, Hundhausen C, Lacy KE, Ali N, et al. Identification of a novel proinflammatory human skin-homing $\mathrm{V} \gamma 9 \mathrm{~V} \delta 2 \mathrm{~T}$ cell subset with a potential role in psoriasis. J Immunol. (2011) 187:2783-93. doi: 10.4049/jimmunol.1100804

60. Matos TR, O’Malley JT, Lowry EL, Hamm D, Kirsch IR, Robins HS, et al. Clinically resolved psoriatic lesions contain psoriasis-specific IL17-producing alphabeta T cell clones. J Clin Invest. (2017) 127:4031-41. doi: 10.1172/JCI93396

61. Mashiko S, Bouguermouh S, Rubio M, Baba N, Bissonnette R, Sarfati M. Human mast cells are major IL-22 producers in patients with psoriasis and atopic dermatitis. J Allergy Clin Immunol. (2015) 136:351-9.e351. doi: 10.1016/j.jaci.2015.01.033

62. Klose CSN, Flach M, Möhle L, Rogell L, Hoyler T, Ebert K, et al. Differentiation of type 1 ILCs from a common progenitor to all helper-like innate lymphoid cell lineages. Cell. (2014) 157:340-56. doi: 10.1016/j.cell.2014.03.030

63. Teunissen MBM, Munneke JM, Bernink JH, Spuls PI, Res PCM, Te Velde A, et al. Composition of innate lymphoid cell subsets in the human skin: 
enrichment of NCR(+) ILC3 in lesional skin and blood of psoriasis patients. J Invest Dermatol. (2014) 134:2351-60. doi: 10.1038/jid.2014.146

64. Dyring-Andersen B, Geisler C, Agerbeck C, Lauritsen JP, Gúdjonsdottir $\mathrm{SD}$, Skov L, et al. Increased number and frequency of group 3 innate lymphoid cells in nonlesional psoriatic skin. Br J Dermatol. (2014) 170:60916. doi: $10.1111 /$ bjd. 12658

65. Villanova F, Flutter B, Tosi I, Grys K, Sreeneebus H, Perera GK, et al. Characterization of innate lymphoid cells in human skin and blood demonstrates increase of NKp44+ ILC3 in psoriasis. J Invest Dermatol. (2014) 134:984-91. doi: 10.1038/jid.2013.477

66. Kobayashi T, Voisin B, Kim DY, Kennedy EA, Jo JH, Shih HY, et al. Homeostatic control of sebaceous glands by innate lymphoid cells regulates commensal bacteria equilibrium. Cell. (2019) 176:982-97.e916. doi: 10.1016/j.cell.2018.12.031

67. Fuchs A, Vermi W, Lee JS, Lonardi S, Gilfillan S, Newberry RD, et al. Intraepithelial type 1 innate lymphoid cells are a unique subset of IL-12- and IL-15-responsive IFN-gamma-producing cells. Immunity. (2013) 38:769-81. doi: 10.1016/j.immuni.2013.02.010

68. Weizman OE, Adams NM, Schuster IS, Krishna C, Pritykin Y, Lau C, et al. ILC1 confer early host protection at initial sites of viral infection. Cell. (2017) 171:795-808.e712. doi: 10.1016/j.cell.2017.09.052

69. Bernink JH, Peters CP, Munneke M, te Velde AA, Meijer SL, Weijer K, et al. Human type 1 innate lymphoid cells accumulate in inflamed mucosal tissues. Nat Immunol. (2013) 14:221-9. doi: 10.1038/ni.2534

70. Fuchs A, Colonna M. Innate lymphoid cells in homeostasis, infection, chronic inflammation and tumors of the gastrointestinal tract. Curr Opin Gastroenterol. (2013) 29:581-7. doi: 10.1097/MOG.0b013e328365d339

71. Roediger B, Kyle R, Yip KH, Sumaria N, Guy TV, Kim BS, et al. Cutaneous immunosurveillance and regulation of inflammation by group 2 innate lymphoid cells. Nat Immunol. (2013) 14:564-73. doi: 10.1038/ ni. 2584

72. Rak GD, Osborne LC, Siracusa MC, Kim BS, Wang K, Bayat A, et al. IL-33dependent group 2 innate lymphoid cells promote cutaneous wound healing. J Invest Dermatol. (2016) 136:487-96. doi: 10.1038/JID.2015.406

73. Salimi M, Barlow JL, Saunders SP, Xue L, Gutowska-Owsiak D, Wang X, et al. A role for IL-25 and IL-33-driven type- 2 innate lymphoid cells in atopic dermatitis. J Exp Med. (2013) 210:2939-50. doi: 10.1084/jem.20130351

74. Iordanov MS, Sundholm AJ, Simpson EL, Hanifin JM, Ryabinina OP, Choi $\mathrm{RJ}$, et al. Cell death-induced activation of epidermal growth factor receptor in keratinocytes: implications for restricting epidermal damage in dermatitis. J Invest Dermatol. (2005) 125:134-42. doi: 10.1111/j.0022-202X.2005.23804.x

75. Imai Y, Yasuda K, Sakaguchi Y, Haneda T, Mizutani H, Yoshimoto T, et al. Skin-specific expression of IL-33 activates group 2 innate lymphoid cells and elicits atopic dermatitis-like inflammation in mice. Proc Natl Acad Sci USA. (2013) 110:13921-6. doi: 10.1073/pnas.1307321110

76. Mashiko S, Mehta H, Bissonnette R, Sarfati M. Increased frequencies of basophils, type 2 innate lymphoid cells and Th2 cells in skin of patients with atopic dermatitis but not psoriasis. J Dermatol Sci. (2017) 88:167-74. doi: 10.1016/j.jdermsci.2017.07.003

77. Brüggen MC, Bauer WM, Reininger B, Clim E, Captarencu C, Steiner GE, et al. In situ mapping of innate lymphoid cells in human skin: evidence for remarkable differences between normal and inflamed skin. J Invest Dermatol. (2016) 136:2396-405. doi: 10.1016/j.jid.2016.07.017

78. Glatzer T, Killig M, Meisig J, Ommert I, Luetke-Eversloh M, Babic M, et al. RORgammat $(+)$ innate lymphoid cells acquire a proinflammatory program upon engagement of the activating receptor NKp44. Immunity. (2013) 38:1223-35. doi: 10.1016/j.immuni.2013.05.013

79. Keren A, Shemer A, Ginzburg A, Ullmann Y, Schrum AG, Paus R, et al. Innate lymphoid cells 3 induce psoriasis in xenotransplanted healthy human skin. J Allergy Clin Immunol. (2018) 142:305-8.e306. doi: 10.1016/j.jaci.2018.02.015

80. Soare A, Weber S, Maul L, Rauber S, Gheorghiu AM, Luber M, et al. Cutting edge: homeostasis of innate lymphoid cells is imbalanced in psoriatic arthritis. J Immunol. (2018) 200:1249-54. doi: 10.4049/jimmunol.1700596

81. Sandrock I, Reinhardt A, Ravens S, Binz C, Wilharm A, Martins J, et al. Genetic models reveal origin, persistence and non-redundant functions of IL-17-producing gammadelta T cells. J Exp Med. (2018) 215:3006-18. doi: $10.1084 /$ jem.20181439
82. Cauza E, Spak M, Cauza K, Hanusch-Enserer U, Dunky A, Wagner E. Treatment of psoriatic arthritis and Psoriasis vulgaris with the tumor necrosis factor inhibitor infliximab. Rheumatol Int. (2002) 22:227-32. doi: 10.1007/s00296-002-0246-3

83. Sutherland DR, Yeo E, Ryan A, Mills GB, Bailey D, Baker MA. Identification of a cell-surface antigen associated with activated $\mathrm{T}$ lymphoblasts and activated platelets. Blood. (1991) 77:84-93. doi: 10.1182/blood.V77.1.84.bloodjournal77184

84. Spits H, Artis D, Colonna M, Diefenbach A, Di Santo JP, Eberl G, et al. Innate lymphoid cells-a proposal for uniform nomenclature. Nat Rev Immunol. (2013) 13:145-9. doi: 10.1038/nri3365

85. Vivier E, Tomasello E, Baratin M, Walzer T, Ugolini S. Functions of natural killer cells. Nat Immunol. (2008) 9:503-10. doi: 10.1038/ni1582

86. Di Santo JP. Functionally distinct NK-cell subsets: developmental origins and biological implications. Eur J Immunol. (2008) 38:2948-51. doi: $10.1002 /$ eji.200838830

87. Sojka DK, Plougastel-Douglas B, Yang L, Pak-Wittel MA, Artyomov MN, Ivanova $\mathrm{Y}$, et al. Tissue-resident natural killer (NK) cells are cell lineages distinct from thymic and conventional splenic NK cells. Elife. (2014) 3:e01659. doi: 10.7554/eLife.01659

88. Hudspeth K, Donadon M, Cimino M, Pontarini E, Tentorio P, Preti M, et al. Human liver-resident CD56(bright)/CD16(neg) NK cells are retained within hepatic sinusoids via the engagement of CCR5 and CXCR6 pathways. J Autoimmun. (2016) 66:40-50. doi: 10.1016/j.jaut.2015.08.011

89. Peng H, Tian Z. Diversity of tissue-resident NK cells. Semin Immunol. (2017) 31:3-10. doi: 10.1016/j.smim.2017.07.006

90. Rosmaraki EE, Douagi I, Roth C, Colucci F, Cumano A, Di Santo JP. Identification of committed NK cell progenitors in adult murine bone marrow. Eur J Immunol. (2001) 31:1900-9. doi: 10.1002/15214141(200106)31:6<1900::aid-immu1900>3.0.co;2-m

91. Yu J, Freud AG, Caligiuri MA. Location and cellular stages of natural killer cell development. Trends Immunol. (2013) 34:573-82. doi: 10.1016/j.it.2013.07.005

92. Gordon SM, Chaix J, Rupp LJ, Wu J, Madera S, Sun JC, et al. The transcription factors T-bet and Eomes control key checkpoints of natural killer cell maturation. Immunity. (2012) 36:55-67. doi: 10.1016/j.immuni.2011.11.016

93. Knox JJ, Cosma GL, Betts MR, McLane LM. Characterization of T-bet and eomes in peripheral human immune cells. Front Immunol. (2014) 5:217. doi: 10.3389/fimmu.2014.00217

94. Aw Yeang HX, Piersma SJ, Lin Y, Yang L, Malkova ON, Miner C, et al. Cutting edge: human CD49e- NK cells are tissue resident in the liver. $J$ Immunol. (2017) 198:1417-22. doi: 10.4049/jimmunol.1601818

95. Luci C, Reynders A, Ivanov II, Cognet C, Chiche L, Chasson L, et al. Influence of the transcription factor RORgammat on the development of NKp46+ cell populations in gut and skin. Nat Immunol. (2009) 10:75-82. doi: 10.1038/ni.1681

96. Buentke E, Heffler LC, Wilson JL, Wallin RP, Löfman C, Chambers BJ, et al. Natural killer and dendritic cell contact in lesional atopic dermatitis skinMalassezia-influenced cell interaction. J Invest Dermatol. (2002) 119:850-7. doi: 10.1046/j.1523-1747.2002.00132.x

97. Ebert LM, Meuter S, Moser B. Homing and function of human skin gammadelta $\mathrm{T}$ cells and NK cells: relevance for tumor surveillance. J Immunol. (2006) 176:4331-6. doi: 10.4049/jimmunol.176. 7.4331

98. Gober MD, Fishelevich R, Zhao Y, Unutmaz D, Gaspari AA. Human natural killer $\mathrm{T}$ cells infiltrate into the skin at elicitation sites of allergic contact dermatitis. J Invest Dermatol. (2008) 128:1460-9. doi: 10.1038/sj.jid. 5701199

99. Simon D, Kozlowski E, Simon H. Natural killer T cells expressing IFNgamma and IL-4 in lesional skin of atopic eczema. Allergy. (2009) 64:1681-4. doi: 10.1111/j.1398-9995.2009.02097.x

100. Rahimpour A, Mattarollo SR, Yong M, Leggatt GR, Steptoe RJ, Frazer IH. gammadelta $\mathrm{T}$ cells augment rejection of skin grafts by enhancing crosspriming of CD8 T cells to skin-derived antigen. J Invest Dermatol. (2012) 132:1656-64. doi: 10.1038/jid.2012.16

101. Kronenberg M, Gapin L. The unconventional lifestyle of NKT cells. Nat Rev Immunol. (2002) 2:557-68. doi: 10.1038/nri854 
102. Schümann J, Voyle RB, Wei BY, MacDonald HR. Cutting edge: influence of the TCR V beta domain on the avidity of CD1d:alpha-galactosylceramide binding by invariant $\mathrm{V}$ alpha 14 NKT cells. J Immunol. (2003) 170:5815-9. doi: 10.4049/jimmunol.170.12.5815

103. Wei DG, Curran SA, Savage PB, Teyton L, Bendelac A. Mechanisms imposing the Vbeta bias of Valpha14 natural killer $\mathrm{T}$ cells and consequences for microbial glycolipid recognition. J Exp Med. (2006) 203:1197-207. doi: 10.1084/jem.20060418

104. Borg NA, Wun KS, Kjer-Nielsen L, Wilce MC, Pellicci DG, Koh $\mathrm{R}$, et al. CD1d-lipid-antigen recognition by the semi-invariant NKT T-cell receptor. Nature. (2007) 448:44-9. doi: 10.1038/nature 05907

105. Ilan Y. Alpha versus beta: are we on the way to resolve the mystery as to which is the endogenous ligand for natural killer T cells? Clin Exp Immunol. (2009) 158:300-7. doi: 10.1111/j.1365-2249.2009.04030.x

106. Pei B, Speak AO, Shepherd D, Butters T, Cerundolo V, Platt FM, et al. Diverse endogenous antigens for mouse NKT cells: self-antigens that are not glycosphingolipids. J Immunol. (2011) 186:1348-60. doi: 10.4049/jimmunol.1001008

107. Coquet JM, Chakravarti S, Kyparissoudis K, McNab FW, Pitt LA, McKenzie BS, et al. Diverse cytokine production by NKT cell subsets and identification of an IL-17-producing CD4-NK1.1- NKT cell population. Proc Natl Acad Sci USA. (2008) 105:11287-92. doi: 10.1073/pnas.0801631105

108. Benlagha K, Kyin T, Beavis A, Teyton L, Bendelac A. A thymic precursor to the NK T cell lineage. Science. (2002) 296:553-5. doi: $10.1126 /$ science. 1069017

109. Pellicci DG, Hammond KJ, Uldrich AP, Baxter AG, Smyth MJ, Godfrey DI. A natural killer T (NKT) cell developmental pathway iInvolving a thymusdependent NK1.1(-)CD4(+) CD1d-dependent precursor stage. J Exp Med. (2002) 195:835-44. doi: 10.1084/jem.20011544

110. Coles MC, Raulet DH. Class I dependence of the development of CD4+ CD8- NK1.1+ thymocytes. J Exp Med. (1994) 180:395-9. doi: 10.1084 /jem.180.1.395

111. Ohteki T, MacDonald HR. Major histocompatibility complex class I related molecules control the development of CD4+8- and CD4-8- subsets of natural killer $1.1+\mathrm{T}$ cell receptor-alpha/beta + cells in the liver of mice. $J$ Exp Med. (1994) 180:699-704. doi: 10.1084/jem.180.2.699

112. Gapin L, Matsuda JL, Surh CD, Kronenberg M. NKT cells derive from double-positive thymocytes that are positively selected by CD1d. Nat Immunol. (2001) 2:971-8. doi: 10.1038/ni710

113. Baev DV, Peng XH, Song L, Barnhart JR, Crooks GM, Weinberg KI, et al. Distinct homeostatic requirements of CD4+ and CD4- subsets of Valpha24-invariant natural killer T cells in humans. Blood. (2004) 104:41506. doi: 10.1182/blood-2004-04-1629

114. Berzins SP, Cochrane AD, Pellicci DG, Smyth MJ, Godfrey DI. Limited correlation between human thymus and blood NKT cell content revealed by an ontogeny study of paired tissue samples. Eur J Immunol. (2005) 35:1399-407. doi: 10.1002/eji.200425958

115. Alberola-Ila J, Hogquist KA, Swan KA, Bevan MJ, Perlmutter RM. Positive and negative selection invoke distinct signaling pathways. J Exp Med. (1996) 184:9-18. doi: 10.1084/jem.184.1.9

116. Ohteki T, Ho S, Suzuki H, Mak TW, Ohashi PS. Role for IL-15/IL-15 receptor beta-chain in natural killer $1.1+\mathrm{T}$ cell receptor-alpha beta + cell development. J Immunol. (1997) 159:5931-5.

117. Eberl G, Lowin-Kropf B, MacDonald HR. Cutting edge: NKT cell development is selectively impaired in Fyn- deficient mice. J Immunol. (1999) 163:4091-4.

118. Walunas TL, Wang B, Wang CR, Leiden JM. Cutting edge: the Ets1 transcription factor is required for the development of NK T cells in mice. J Immunol. (2000) 164:2857-60. doi: 10.4049/jimmunol.164.6.2857

119. Matsuda JL, Zhang Q, Ndonye R, Richardson SK, Howell AR, Gapin L. T-bet concomitantly controls migration, survival, and effector functions during the development of Valpha14i NKT cells. Blood. (2006) 107:2797-05. doi: 10.1182/blood-2005-08-3103

120. Bendelac A, Rivera MN, Park SH, Roark JH. Mouse CD1-specific NK1 T cells: development, specificity, and function. Annu Rev Immunol. (1997) 15:535-62. doi: 10.1146/annurev.immunol.15.1.535
121. Metelitsa LS, Naidenko OV, Kant A, Wu HW, Loza MJ, Perussia $B$, et al. Human NKT cells mediate antitumor cytotoxicity directly by recognizing target cell CD1d with bound ligand or indirectly by producing IL-2 to activate NK cells. J Immunol. (2001) 167:3114-22. doi: 10.4049/jimmunol.167.6.3114

122. Yu JS, Hamada M, Ohtsuka S, Yoh K, Takahashi S, Miaw SC. Differentiation of IL-17-producing invariant natural killer $\mathrm{T}$ cells requires expression of the transcription factor c-Maf. Front Immunol. (2017) 8:1399. doi: 10.3389/fimmu.2017.01399

123. Venken K, Jacques P, Mortier C, Labadia ME, Decruy T, Coudenys J, et al. RORgammat inhibition selectively targets IL-17 producing iNKT and gammadelta-T cells enriched in Spondyloarthritis patients. Nat Commun. (2019) 10:9. doi: 10.1038/s41467-018-07911-6

124. Brigl M, Bry L, Kent SC, Gumperz JE, Brenner MB. Mechanism of CD1drestricted natural killer $\mathrm{T}$ cell activation during microbial infection. Nat Immunol. (2003) 4:1230-7. doi: 10.1038/ni1002

125. Goubier A, Vocanson M, Macari C, Poyet G, Herbelin A, Nicolas JF, et al. Invariant NKT cells suppress CD8(+) T-cell-mediated allergic contact dermatitis independently of regulatory CD4(+) T cells. J Invest Dermatol. (2013) 133:980-7. doi: 10.1038/jid.2012.404

126. Nieuwenhuis EE, Gillessen S, Scheper RJ, Exley MA, Taniguchi M, Balk SP, et al. CD1d and CD1d-restricted iNKT-cells play a pivotal role in contact hypersensitivity. Exp Dermatol. (2005) 14:250-8. doi: 10.1111/j.0906-6705.2005.00289.x

127. Askenase PW, Majewska-Szczepanik M, Kerfoot S, Szczepanik M. Participation of iNKT cells in the early and late components of Tc1mediated DNFB contact sensitivity: cooperative role of gammadelta-T cells. Scand J Immunol. (2011) 73:465-77. doi: 10.1111/j.1365-3083.2011.02522.x

128. Eguchi T, Kumagai K, Kobayashi H, Shigematsu H, Kitaura K, Suzuki $S$, et al. Accumulation of invariant NKT cells into inflamed skin in a novel murine model of nickel allergy. Cell Immunol. (2013) 284:163-71. doi: 10.1016/j.cellimm.2013.07.010

129. Takahashi T, Nakamura K, Chiba S, Kanda Y, Tamaki K, Hirai H. V alpha 24+ natural killer $\mathrm{T}$ cells are markedly decreased in atopic dermatitis patients. Hum Immunol. (2003) 64:586-92. doi: 10.1016/S0198-8859(03)00066-1

130. Zeng D, Lewis D, Dejbakhsh-Jones S, Lan F, García-Ojeda M, Sibley $\mathrm{R}$, et al. Bone marrow NK1.1(-) and NK1.1(+) T cells reciprocally regulate acute graft versus host disease. J Exp Med. (1999) 189:1073-81. doi: 10.1084/jem.189.7.1073

131. Chan JR, Blumenschein W, Murphy E, Diveu C, Wiekowski M, Abbondanzo S, et al. IL-23 stimulates epidermal hyperplasia via TNF and IL-20R2dependent mechanisms with implications for psoriasis pathogenesis. J Exp Med. (2006) 203:2577-87. doi: 10.1084/jem.20060244

132. Leveson-Gower DB, Olson JA, Sega EI, Luong RH, Baker J, Zeiser R, et al. Low doses of natural killer $\mathrm{T}$ cells provide protection from acute graft-versushost disease via an IL-4-dependent mechanism. Blood. (2011) 117:3220-29. doi: 10.1182/blood-2010-08-303008

133. Batista MD, Ho EL, Kuebler PJ, Milush JM, Lanier LL, Kallas EG, et al. Skewed distribution of natural killer cells in psoriasis skin lesions. Exp Dermatol. (2013) 22:64-6. doi: 10.1111/exd.12060

134. Mori H, Arita K, Yamaguchi T, Hirai M, Kurebayashi Y. Effects of topical application of betamethasone on imiquimod-induced psoriasis-like skin inflammation in mice. Kobe J Med Sci. (2016) 62:E79-88.

135. Chiricozzi A, Guttman-Yassky E, Suárez-Fariñas M, Nograles KE, Tian S, Cardinale I, et al. Integrative responses to IL-17 and TNF-alpha in human keratinocytes account for key inflammatory pathogenic circuits in psoriasis. J Invest Dermatol. (2011) 131:677-87. doi: 10.1038/jid.2 010.340

136. Boehncke WH, Schon MP. Psoriasis. Lancet. (2015) 386:983-94. doi: 10.1016/S0140-6736(14)61909-7

137. Kristensen M, Chu CQ, Eedy DJ, Feldmann M, Brennan FM, Breathnach SM.Localization of tumour necrosis factor-alpha (TNF-alpha) and its receptors in normal and psoriatic skin: epidermal cells express the $55-\mathrm{kD}$ but not the 75-kD TNF receptor. Clin Exp Immunol. (1993) 94:354-62. doi: 10.1111/j.1365-2249.1993.tb03457.x

138. Ettehadi P, Greaves MW, Wallach D, Aderka D, Camp RD. Elevated tumour necrosis factor-alpha (TNF-alpha) biological activity 
in psoriatic skin lesions. Clin Exp Immunol. (1994) 96:146-51. doi: 10.1111/j.1365-2249.1994.tb06244.x

139. Kumari S, Bonnet MC, Ulvmar MH, Wolk K, Karagianni N, Witte E, et al. Tumor necrosis factor receptor signaling in keratinocytes triggers interleukin-24-dependent psoriasis-like skin inflammation in mice. Immunity. (2013) 39:899-911. doi: 10.1016/j.immuni.2013.10.009

140. Kaushik SB, Lebwohl MG. Psoriasis: which therapy for which patient: psoriasis comorbidities and preferred systemic agents. J Am Acad Dermatol. (2019) 80:27-40. doi: 10.1016/j.jaad.2018.06.057

141. Kagami S, Rizzo HL, Kurtz SE, Miller LS, Blauvelt A. IL-23 and IL-17A, but not IL-12 and IL-22, are required for optimal skin host defense against Candida albicans. J Immunol. (2010) 185:5453-62. doi: 10.4049/jimmunol.1001153

142. Bär E, Whitney PG, Moor K, Reis e Sousa C, LeibundGut-Landmann S. IL-17 regulates systemic fungal immunity by controlling the functional competence of NK cells. Immunity. (2014) 40:117-27. doi: 10.1016/j.immuni.2013.12.002

143. Cupedo T, Crellin NK, Papazian N, Rombouts EJ, Weijer K, Grogan JL, et al. Human fetal lymphoid tissue-inducer cells are interleukin 17-producing precursors to RORC+CD127+ natural killer-like cells. Nat Immunol. (2009) 10:66-74. doi: 10.1038/ni.1668

144. Crellin NK, Trifari S, Kaplan CD, Cupedo T, Spits H. Human NKp44+IL$22+$ cells and LTi-like cells constitute a stable RORC+ lineage distinct from conventional natural killer cells. J Exp Med. (2010) 207:281-90. doi: 10.1084/jem.20091509

145. Bata-Csorgo Z, Hammerberg C, Voorhees JJ, Cooper KD. Kinetics and regulation of human keratinocyte stem cell growth in shortterm primary ex vivo culture. Cooperative growth factors frompsoriatic lesional $\mathrm{T}$ lymphocytes stimulate proliferation among psoriatic uninvolved, but not normal, stem keratinocytes. J Clin Invest. (1995) 95:317-27. doi: 10.1172/JCI117659

146. Cheuk S, Schlums H, Gallais Sérézal I, Martini E, Chiang SC, Marquardt $\mathrm{N}$, et al. CD49a expression defines tissue-resident CD8(+) $\mathrm{T}$ cells poised for cytotoxic function in human skin. Immunity. (2017) 46:287-300. doi: 10.1016/j.immuni.2017.01.009

147. Liao YH, Jee SH, Sheu BC, Huang YL, Tseng MP, Hsu SM, et al. Increased expression of the natural killer cell inhibitory receptor CD94/NKG2A and CD158b on circulating and lesional $\mathrm{T}$ cells in patients with chronic plaque psoriasis. Br J Dermatol. (2006) 155:318-24. doi: 10.1111/j.1365-2133.2006.07301.x

148. Netea MG, Joosten LA, Latz E, Mills KH, Natoli G, Stunnenberg HG, et al. Trained immunity: a program of innate immune memory in health and disease. Science. (2016) 352:aaf1098. doi: 10.1126/science. aaf1098

Conflict of Interest: The authors declare that the research was conducted in the absence of any commercial or financial relationships that could be construed as a potential conflict of interest.

Copyright (C) 2020 Polese, Zhang, Thurairajah and King. This is an open-access article distributed under the terms of the Creative Commons Attribution License (CC BY). The use, distribution or reproduction in other forums is permitted, provided the original author(s) and the copyright owner(s) are credited and that the original publication in this journal is cited, in accordance with accepted academic practice. No use, distribution or reproduction is permitted which does not comply with these terms. 